\title{
Nitric Oxide Signaling and Its Association with Ubiquitin-Mediated Proteasomal Degradation in Plants
}

\author{
Anjali Pande ${ }^{1, *} \mathbb{*}$, Bong-Gyu Mun ${ }^{1}$, Murtaza Khan ${ }^{1}$, Waqas Rahim ${ }^{1}$, Da-Sol Lee ${ }^{1}$, Geun-Mo Lee ${ }^{1}$, \\ Tiba Nazar Ibrahim Al Azawi ${ }^{1}$, Adil Hussain ${ }^{2} \mathbb{D}$ and Byung-Wook Yun ${ }^{1, *} \mathbb{C}$
}

check for updates

Citation: Pande, A.; Mun, B.-G.;

Khan, M.; Rahim, W.;

Lee, D.-S.; Lee, G.-M.;

Al Azawi, T.N.I.; Hussain, A.;

Yun, B.-W. Nitric Oxide Signaling and Its Association with UbiquitinMediated Proteasomal Degradation in Plants. Int. J. Mol. Sci. 2022, 23, 1657. https://doi.org/10.3390/ ijms23031657

Academic Editors: Zhihua Hua and Richard S. Marshall

Received: 6 January 2022

Accepted: 29 January 2022

Published: 31 January 2022

Corrected: 18 May 2022

Publisher's Note: MDPI stays neutral with regard to jurisdictional claims in published maps and institutional affiliations.

Copyright: (c) 2022 by the authors. Licensee MDPI, Basel, Switzerland. This article is an open access article distributed under the terms and conditions of the Creative Commons Attribution (CC BY) license (https:// creativecommons.org/licenses/by/ $4.0 /)$.
1 Laboratory of Plant Molecular Pathology and Functional Genomics, Department of Plant Biosciences, School of Applied Biosciences, College of Agriculture \& Life Science, Kyungpook National University, Daegu 41944, Korea; mun0301@naver.com (B.-G.M.); murtazakhan.bio@gmail.com (M.K.); waqasrahim999@yahoo.com (W.R.); giftanna@naver.com (D.-S.L.); looxia@naver.com (G.-M.L.); redflower660@yahoo.com (T.N.I.A.A.)

2 Laboratory of Cell Biology, Department of Entomology, Abdul Wali Khan University, Mardan 23200, Khyber Pakhtunkhwa, Pakistan; adilhussain@awkum.edu.pk

* Correspondence: anjali.pande23@gmail.com (A.P.); bwyun@knu.ac.kr (B.-W.Y.)

\begin{abstract}
Nitric oxide (NO) is a versatile signaling molecule with diverse roles in plant biology. The NO-mediated signaling mechanism includes post-translational modifications (PTMs) of target proteins. There exists a close link between NO-mediated PTMs and the proteasomal degradation of proteins via ubiquitylation. In some cases, ubiquitin-mediated proteasomal degradation of target proteins is followed by an NO-mediated post-translational modification on them, while in other cases NO-mediated PTMs can regulate the ubiquitylation of the components of ubiquitin-mediated proteasomal machinery for promoting their activity. Another pathway that links NO signaling with the ubiquitin-mediated degradation of proteins is the $\mathrm{N}$-degron pathway. Overall, these mechanisms reflect an important mechanism of NO signal perception and transduction that reflect a close association of NO signaling with proteasomal degradation via ubiquitylation. Therefore, this review provides insight into those pathways that link NO-PTMs with ubiquitylation.
\end{abstract}

Keywords: nitric oxide; ubiquitylation; S-nitrosylation; proteasome; proteolysis

\section{Introduction}

Nitric oxide (NO) is a highly reactive and unstable gas with a short half-life. However, it is one of the most versatile signaling molecules in the biological system. The hunt for the presence of nitric oxide in plants began in the year 1998 [1,2], soon after its identification in the mammalian system in the year 1987 [3]. In plants, it is involved in various growth, developmental [4,5], and environmental stress acclimation processes [1,2,6]. In addition, $\mathrm{NO}$ is also involved in the signaling pathways that lead to programed cell death [7-10]. The main mechanism of action of NO in plants is through the post-translational modifications of proteins that are involved in cell signaling under physiological and stress conditions [11-13]. The NO-mediated PTMs predominantly comprise of S-nitrosylation, tyrosine nitration, and metal nitrosylation of target proteins. However, targeted proteolysis of group VII Ethylene Response Factors (ERFs-VII) transcription factor (TFs) via the N-end rule pathway [14,15] is suggested to be a general homeostatic mechanism of NO sensing in plants. This pathway was recently named as the $\mathrm{N}$-degron pathway of protein degradation [16].

Ubiquitylation is a major pathway regulating proteolysis in eukaryotes $[17,18]$. In plants, it regulates several developmental processes indicating its diverse role throughout the life cycle of plants. Moreover, it regulates many signal transduction pathways, mostly those related to a plant's response under environmental stress, by rapidly enhancing or degrading the proteins through the $26 \mathrm{~S}$ proteasome, depending upon their requirements during the stress response [19]. In this pathway, multiple ubiquitin proteins are conjugated 
to the target protein as labels or tags (a process called ubiquitylation). The tagged proteins are directed to the $26 \mathrm{~S}$ proteasome for degradation [19-22]. However, it is interesting to note that plants possess other degradation systems similar to ubiquitylation, such as autophagy and SUMOylation, that involve ubiquitin-like modifiers, namely ATG8 (autophagy-related protein 8 ) and small ubiquitin like-modifier (SUMO), respectively. Just as ubiquitin marks the proteins for degradation in the process of ubiquitylation, similarly, ATG8 surrounds the autophagosome (a double-membrane vesicle) during autophagy. Intriguingly, ubiquitin also serves in many selective autophagy processes, thus acting as a common factor for the Ubiquitin Proteasome System (UPS) and autophagy. Moreover, autophagy can also degrade components of UPS such as the $26 \mathrm{~S}$ proteasome, while UPS can degrade the autophagosome markers, the ATGs [23].

Like Ubiquitylation, SUMOylation also involves the covalent attachment of small ubiquitin-like modifier (SUMO) to the lysine residue on the target protein. Although ubiquitin marks the target proteins for degradation, SUMOylation changes the fate of target proteins by altering their stability or interaction with other partners (proteins or DNA) [24]. However, there exists a point of interaction between SUMOylation and ubiquitylation in multiple pathways, as suggested by Denuc and Marfany [25], which is supportive of their convergent evolution in the plant system $[19,26]$.

Although NO plays regulatory roles in autophagy [27-29] and SUMOylation [11,30,31], this review mainly focuses on the NO-mediated signaling and its association with ubiquitylation. Therefore, in this review, we have discussed the relationship between nitric oxide sensing via NO-mediated PTMs of target proteins and the N-degron pathway, which are associated with ubiquitin-mediated proteasomal degradation. These mechanisms highlight a valuable role of NO signal perception and transduction in plants.

\section{An Overview of the Mechanism of Ubiquitylation in Plants}

Ubiquitin-mediated proteasomal degradation or ubiquitylation is a post-translational modification involving the addition of multiple (a chain of four or more) ubiquitin tags to the target protein, and thereafter directing it to $26 \mathrm{~S}$ proteasome for degradation. The ligation of ubiquitin on the lysine residue of the target protein (monoubiquitylation) is carried out by 3 enzymes, namely ubiquitin-activating enzymes (E1), ubiquitin-conjugating enzymes (E2) and ubiquitin ligases (E3) [21]. The adenylation of the C-terminus of ubiquitin is catalyzed by E1 which allows it to form a thioester bond between the active site cysteine of E1 and the carboxylate group of ubiquitin's C-terminus [32]. Thereafter, the activated ubiquitin gets transferred to a cysteine residue of an E2 enzyme through a thioester bond. Finally, the covalent attachment of ubiquitin (together with the E2 enzyme) to the substrate proteins takes place through the activity of substrate-specific E3 ligase [21]. In flowering plants, there are more than one enzyme that perform the function of E1, E2 or E3 enzymes. For instance, Arabidopsis ubiquitin-activating enzymes, UBA1 and UBA2, carry out the function of E1 enzymes [33], and there is prediction of 37 E2 enzymes encoded in the genome [34]. Interestingly, the identification of around 1500 gene encoding components of E3 ligases in Arabidopsis depicts the vast substrate specificity and the significance of the ubiquitin system in plants as compared to other eukaryotes [35]. Moreover, the activity of a fourth enzyme, E4 ligase may be involved in the elongation of the polyubiquitin chains [36]. In Arabidopsis, the identification of an E4 ligase, MUTANT, SNC1-Enhancing (MUSE3) was found to be involved in the polyubiquitination of immune receptors, NLRs (proteins with nucleotide binding and leucine-rich repeat domains) [37].

Once the ubiquitin tags are attached to the substrate protein, they are targeted to the $26 \mathrm{~S}$ proteasome for proteolysis [38]. The $26 \mathrm{~S}$ proteasome is found in all eukaryotic cells and is located in the cytosol and nucleus as a $2.5 \mathrm{MDa}$, multi-subunit protease [39-42]. It is composed of 2 separately stable sub-complexes, the $20 \mathrm{~S}$ core protease $(\mathrm{CP})$ and the 195 regulatory particle (RP). RP is the outer cap-like structure on one or both ends, involved in capturing and preparing the appropriate substrate for degradation, while $\mathrm{CP}$ is a barrel shaped structure involved in peptidase activities [43-45]. The polyubiquitylated conjugate 
can either be broken down by the $26 \mathrm{~S}$ proteasome or disassembled by the hydrolytic activity of deubiquitinating enzymes (DUBs) releasing the bound ubiquitin moieties for further use. Recent studies suggest that a variety of cellular processes in plants are regulated by DUBs in plants, such as the regulation of plant immunity [46] and in jasmonic acid signaling [47].

\section{NO-Mediated Ubiquitylation Process in Plant Development and Stress Management}

The fact that NO is a key signaling molecule involved in a plethora of physiological processes regulating plant growth, development and stress acclimation suggests that NO signal perception, transduction, and response regulation is rather more complex than studied so far. The regulation of processes like ubiquitylation indicates the active involvement of NO in maintaining the cellular levels of proteins, also known as "cellular proteostasis", participating in various growth, development and stress acclimation pathways. In this context, the first identified NO sensing mediated by the N-degron pathway relates the regulation of the in vivo half-life of a protein based on the N-terminal residue [16]. The substrates of this pathway, such as the ETHYLENE RESPONSE FACTOR VII (ERF-VII) family of transcription factors [48], the Polycomb Repressor Complex 2 component VERNALIZATION (VRN) 2 [49] and LITTLE ZIPPER 2 (ZPR2) transcription factor [50], are destabilized by this pathway, thus regulating seed germination [51], shoot and leaf development [52], gametophyte development [53], enhanced hypoxia tolerance ([48], enhanced tolerance to abiotic stress such as drought and salt [54], recovery after dark, submergence and starvation [55], and various pathogen responses [56]. Furthermore, the enzymatic components of the N-degron pathway are also involved in seed ripening, lipid breakdown, hormone signaling and germination [57]. Though the N-degron pathway explains the link between NO sensing and proteolytic regulation to control physiological processes in plants, many associated substrates and components of different pathways associated with them still need to be identified to fully appreciate this versatile pathway in plant.

Furthermore, the expanding literature on NO sensing through NO-mediated PTMs suggests another level of control by NO in regulating the physiological responses in plants. The delicate levels of phytohormones like auxins, abscisic acid and salicylic acid involved in various growth and developmental processes and also abiotic and biotic stress responses are regulated by S-nitrosylation. A few components involved in phytohormonal synthesis, conjugation and signaling undergo ubiquitylation, thus mediating a response regulation in plants. For instance, ABI5, PYR1, TIR1, APX1 and NPR1 (discussed later in the review) are all part of the phytohormonal signaling.

\section{Ubiquitylation as Part of NO Sensing in Plants: The N-Degron Pathway}

Reports suggest the ubiquitin-proteasome pathway acts as part of the NO sensing mechanism in plants through the ERFs-VII group of TFs [15]. The group ERFs-VII are TFs that form a phylogenetic cluster in the large ERF TFs family which comprise a large number of elements specified in plants [58]. The stability of ERF-VII TFs is regulated by intracellular oxygen and NO levels through the N-end rule pathway (or the N-degron) [15]. This regulation was first studied under hypoxic (low oxygen) conditions [48]. It is noteworthy here that even under hypoxic conditions, various biochemical pathways, including the energy production pathways, lead to the production of reactive oxygen species (ROS) $[59,60]$. This process is similar to the one that occurs in mammalian cells under hypoxia, suggesting that ROS are produced in the modulation of hypoxic signaling [61]. This hypoxic signaling enables plants to sense the low environmental oxygen levels through the hypoxia-responsive transcription factors, such as ERF-VII TFs groups [62]. In flowering plants, this pathway was found to require NO in addition to oxygen [14]. This indicated that the N-end rule pathway is also an NO sensor in plants [15]. Thus, according to this pathway, in the presence of low oxygen and NO, ERFs-VII TFs are destabilized due to the cleavage of N-terminal methionine by endopeptidase or its cotranslational cleavage by aminopeptidases (MAPs), exposing the second cysteine residue (Cys2) of the ERF transcription factor for oxidation by plant cysteine oxidases (PCOs). The oxidation of Cys2 is 
further arginylated by arginine-tRNA (Arg-tRNA) and catalyzed by arginyl-transferase (ATE) $[63,64]$, followed by recognition of the arginine destabilizing residue by N-recognins (PRT6; proteolysis six E3 ligase) and the ubiquitin proteasomal system which leads them to the $26 \mathrm{~S}$ proteasome for degradation (Figure 1 ).

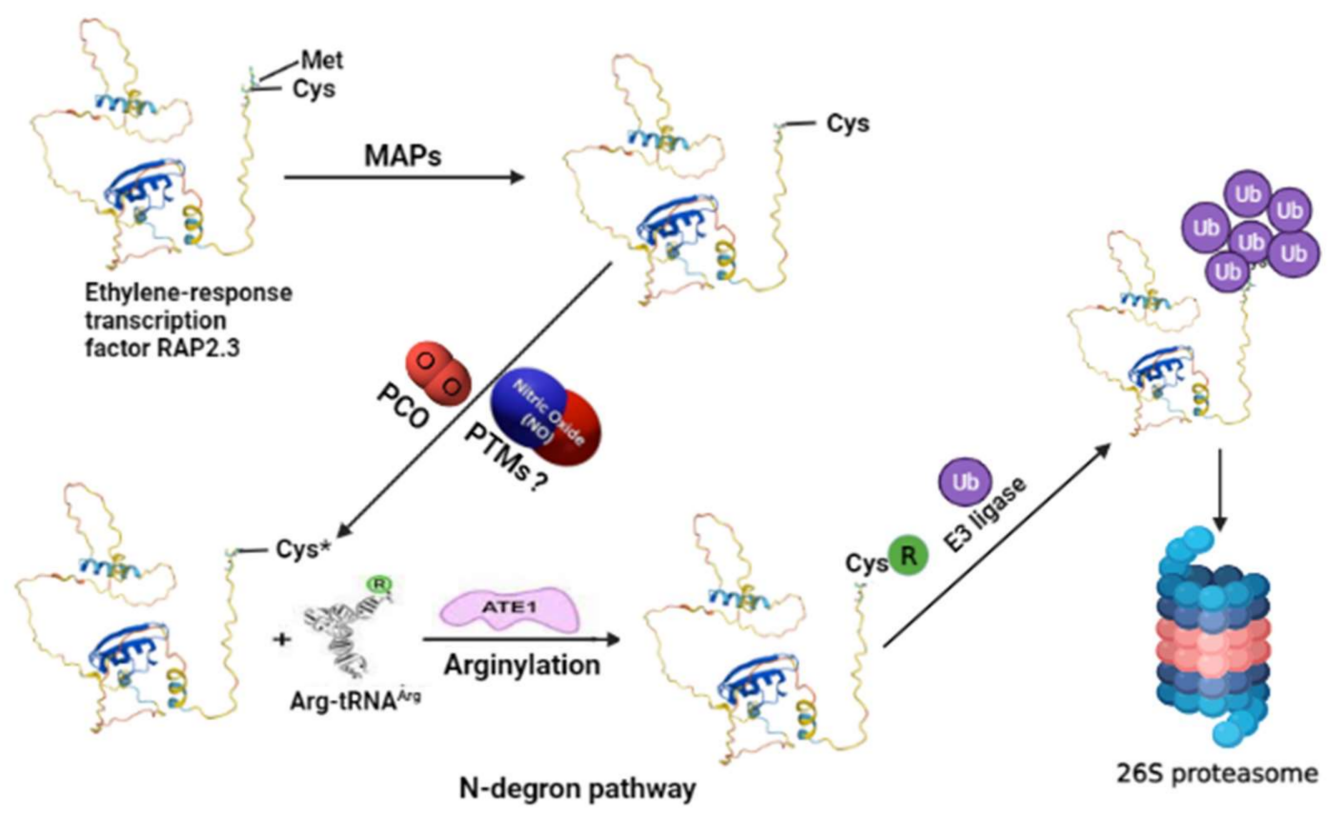

Figure 1. An exemplified model for understanding the N-degron pathway involving ubiquitin proteasomal degradation of ERF-VII (for example, RELATED TO AP2 3, RAP2.3) TF as a part of the NO sensing mechanism in plants. The N-terminal methionine is cleaved by MAPs exposing the second residue, cysteine (Cys). Cysteine gets oxidized by the action of PCOs. In this step, the role of NO is also reported, so possible NO-mediated oxidation of cysteine residue via PTMs still needs to be explored. The oxidized cysteine (Cys*) of the target protein then undergoes arginylation by Arg-tRNA and is catalyzed by ATE1, which helps in its recognition by PRT6 N-recognin for its ubiquitin-mediated proteolysis. MAPs—aminopeptidases; PCOs—plant cysteine oxidases; PTMs-post-translational modifications; ATE1-arginyl-transferases; PRT6-proteolysis 6 E3 ligases. The model structure of RAP2.3 was obtained from UniProt (https://www.uniprot.org/uniprot/P42736\#structure accessed on 19 December 2021). The structure of Arg-tRNA Arg and ATE1 is reprinted (adapted) with permission from [65].

In a study, Arabidopsis proteome analysis depicted only 246 potential targets of the N-degron pathway [14]. This also indicates the specificity and the limitation of protein regulation by the $\mathrm{N}$-degron mechanism, and particular biological responses. Some of the potential targets of the N-degron pathway, other than ERF-VII TFs, include VRN2 (vernalization 2) [66], PRC-2 (a subunit of the polycomb repressive complex) [49], and ZPR2 (little zipper 2 transcription factor) [50].

\section{NO-Mediated PTMs Associated with Ubiquitin-Mediated Proteolysis}

NO signal perception and transduction occur through NO-mediated post-translational modifications (PTM) of target proteins in plants. NO-mediated PTMs include S-nitrosylation, where NO reacts with the thiol group of cysteine (Cys) residue to form S-nitrosothiol; tyrosine nitration, the formation of 3-nitrotyrosine by peroxynitrite (NO-derived species); and metal nitrosylation, the binding of NO to transition metals of metalloproteins [12]. Recent studies suggest that the addition of $\mathrm{NO}$ to reactive Cys thiols, in the process of S-nitrosylation of proteins, may act as a key mechanism of NO signaling in plants [13,67].

Moreover, S-nitrosylation is a well-studied, essential regulatory PTM involved in plant immune responses [68]. Several other processes involve proteins that are potential targets 
for S-nitrosylation in Arabidopsis [69]. Proteins involved in plant immune response are wellstudied targets of s-nitrosylation. These include NADPH oxidase [70,71], SALICYLIC ACIDBINDING PROTEIN 3 (SABP3) [72], NON-EXPRESSOR OF PATHOGENESIS-RELATED GENES 1 (NPR1) [73], TGACG-binding factor 1 (TGA1) [74], ASCORBATE PEROXIDASE 1 (APX1) [75], etc. Out of these, S-nitrosylation of APX1 and ABI5 (ABA INSENSITIVE 5) are reported to undergo degradation through the ubiquitin-proteasome pathway, while NPR1 is protected from ubiquitylation after S-nitrosylation [76-78]. However, soluble receptors in ABA signaling are targets of tyrosine nitration but are directed for proteasomal degradation in a similar manner.

Ascorbate peroxidases are key antioxidative enzymes, involved in scavenging $\mathrm{H}_{2} \mathrm{O}_{2}$ using ascorbate as an electron donor. The cytosolic isoform of ascorbate peroxidase, apx1, plays a key role in regulating $\mathrm{H}_{2} \mathrm{O}_{2}$ levels under abiotic stress conditions $[59,79]$ and also constitutes an essential part of the control of redox metabolism during plant immune responses [80]. Recent reports have suggested that S-nitrosylation, nitration, and metal nitrosylation regulate APX1 activity during different cellular processes [81]. Under oxidative stress, S-nitrosylation of APX1 is suggested to enhance the enzymatic activity of APX1 in scavenging hydrogen peroxide [75]. Interestingly, a study discussed that Snitrosylation of CAPX induces its ubiquitylation and degradation which acts as a signaling mechanism of programed cell death in tobacco cells [76]. This study reports that hydrogen peroxide induces programed cell death in tobacco cells through S-nitrosylation of cAPX which drives it to ubiquitin-mediated proteasomal degradation (as shown in Figure 2b). Moreover, the treatment of cells with an NO scavenger, cPTIO (2-4-carboxyphenyl-4,4,5,5tetramethylimidazoline-1-oxyl-3-oxide), remarkably prevented ubiquitylation and degradation of CAPX, indicating that S-nitrosylation is a signal for ubiquitin-mediated protein degradation. Such a mechanism was found to be similar in animals where S-nitrosylation is a direct signal for ubiquitin-mediated protein degradation [82].

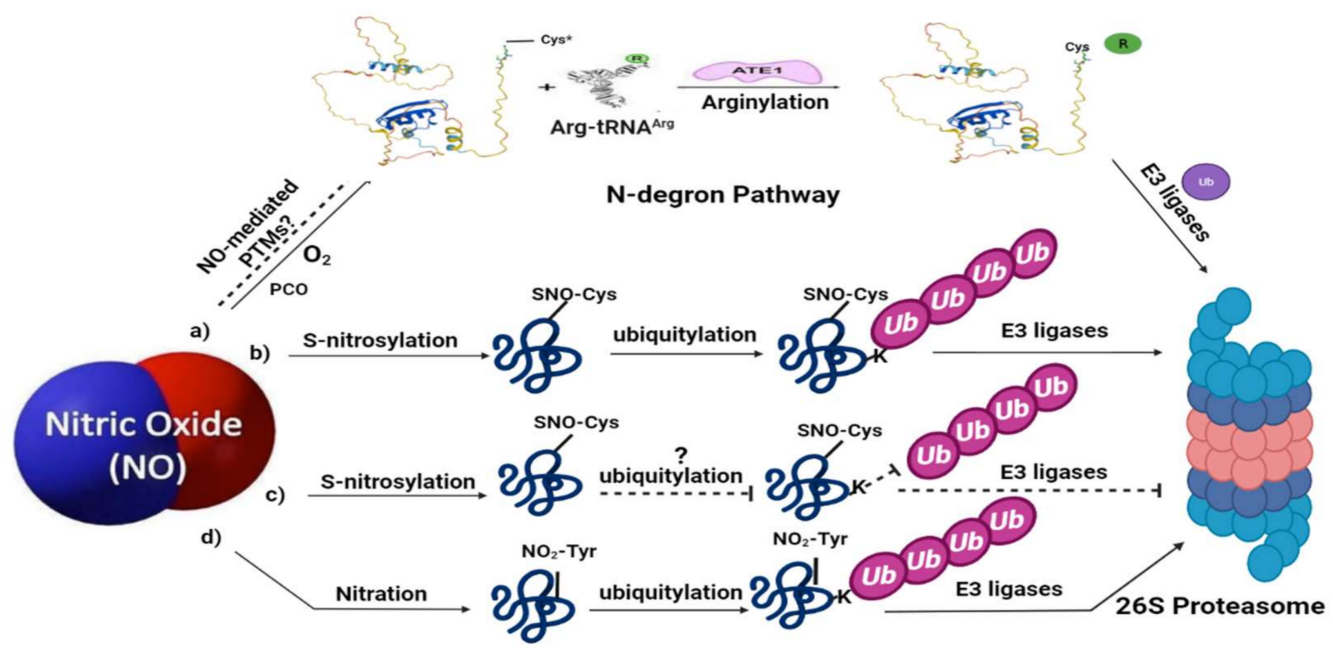

Figure 2. Nitric oxide signaling associated with ubiquitin-mediated proteolysis in plants: (a) represents the N-degron pathway (already described in detail in Figure 1); (b) under certain environmental conditions, NO can trigger ubiquitin-mediated proteasomal degradation of some proteins via $S$ nitrosylation, for example, APX1 and ABI5; (c) meanwhile, NO can also protect certain proteins by preventing their degradation via S-nitrosylation; (d) NO-mediated PTMs, such as tyrosine nitration, also leads to the proteolytic degradation via ubiquitin-mediated PTMs. Limited evidence is available for these pathways in plants; therefore, the dashed lines and question marks are used which represent further clarification of these signaling pathways in plants. SNO represents $S$-nitrosothiol; $\mathrm{NO}_{2}-\mathrm{Tyr}$ represents tyrosine nitration. The structure of Arg-tRNA ${ }^{\mathrm{Arg}}$ and ATE1 is reprinted (adapted) with permission from [65]. 
ABI5 (ABA INSENSITIVE 5) is a basic leucine zipper-type transcription factor, which is regulated by the stress hormone, abscisic acid (ABA). It is responsible for the ABA-induced growth arrest after germination. This effect is counteracted by $\mathrm{NO}$ during seed germination. It has been reported that in the presence of NO, S-nitrosylation of ABI5 occurs which is followed by its catalytic degradation through CULLIN4-based and KEEP ON GOING E3 ligases, thus promoting seed germination [78] (as shown in Figure 2b). ABA signaling also involves ligand binding by a PYRABACTIN RESISTANCE1/PYR1-LIKE/REGULATORY COMPONENT (PYR/PYL/RCR) family of soluble receptors and the interaction of this receptor-ligand complex with the PP2C family of PROTEIN PHOSPHATASES 2C [83,84]. This complex inhibits phosphatase activity, enabling the ABA-activated SUCROSE NONFERMENTING1 KINASES RELATED SUBFAMILY 2 (SnRK2) protein kinase family () to remain phosphorylated and initiate the phosphorylation of ABA-responsive TFs. Since $\mathrm{NO}$ exerts a negative effect on ABA signaling [85] it is reported that NO mediates the tyrosine nitration of ABA receptors of the PYR/PYL/RCAR family [86]. Tyrosine nitration of these ABA receptors reduces their activity and they are polyubiquitylated for proteasomemediated degradation [86] (as shown in Figure 2d), thus limiting the phosphorylation of ABA-responsive TFs and negatively affecting the ABA signaling response.

NPR1 (NON-EXPRESSOR OF PATHOGENESIS-RELATED GENES 1) is a key player in the establishment of salicylic acid (SA)-induced systemic acquired resistance [46] and induced systemic response (ISR) in response to pathogen challenge in plants $[87,88]$. NPR1 exists as an oligomer in the cytoplasm under non-stress conditions. However, under stress conditions, an oxidative burst leads to its monomerization, nuclear localization, and thereafter, the expression of pathogenesis-related (PR) genes [89]. This oligomer-monomer switch involves S-nitrosylation of NPR1 on cysteine 156, which translocates it to the nucleus and allows further interaction with the TGA TF (another target for S-nitrosylation) for the transcription of PR genes [74,89]. However, NPR1 is ubiquitinylated and undergoes proteasomal degradation in the absence of a pathogen. It has been reported that NPR1 undergoes stepwise ubiquitylation by CULLIN3-RING E3 ligase and E4 ligase, respectively, for catalyzing polyubiquitylation [30,90]. A study by Ding et al. [77] suggests that where ABA promotes the ubiquitin-mediated proteasomal degradation of NPR1, S-nitrosylation could protect it (as shown in Figure 2c).

\section{NO-Mediated PTMs Regulate the Components of Ubiquitin-Mediated Proteolysis}

NO-mediated PTMs can not only modify the target protein but can also modify the components of the ubiquitylation machinery, including E1-E3 enzymes and the proteasome for promoting or inhibiting degradation of the target protein. This mechanism has been well studied in animals [91-93]. In plants, however, more studies are required to project a clear picture of this mechanism. So far, a few studies have reported S-nitrosylation of the E3 ligase complex that amplifies its effect on the target protein for degradation. In Arabidopsis, it includes a ubiquitin-activating enzyme, an alpha-subunit, and a regulatory subunit of $26 \mathrm{~S}$ proteasome as targets of S-nitrosylation [94]. Another example is the TRANSPORT INHIBITOR RESPONSE 1/AUXIN SIGNALING F-BOX (TIR1/AFB) protein which is a substrate receptor subunit of the E3-ubiquitin ligase complex, SCF TIR1/AFB This complex is responsible for the degradation of AUXIN/INDOLE-3-ACETIC ACID (Aux/IAA) repressors to induce auxin-regulated responses. S-nitrosylation of the TIR1 auxin receptor at Cys140 enhances the TIR1-Aux/IAA interaction, and thus facilitates its ubiquitylation and degradation while promoting the auxin-regulated response [95].

Another interesting candidate with immediate links with the ubiquitin pathway is CELL DIVISION CONTROL 48, CDC48 (p97). In yeast, plants, and animals, CDC48, a cell division control protein also known as p97 or VALOSIN-CONTAINING PROTEIN (VCP), is present, which belongs to the evolutionary conserved ATPase of the AAA family. This abundant protein plays a major regulatory role in a broad array of cellular processes, particularly the proteasome-dependent degradation of ubiquitylated proteins, redox regulation, and subcellular trafficking $[96,97]$. Of particular interest is its 'segregase' activity which involves 
segregating ubiquitylated substrates from unmodified partners. S-nitrosylation of CDC48 at conserved cysteine residues inhibits its ATPase activity [98] during the host-pathogen interaction between Nicotiana tabacum and Phytopthora cryptogea. During their interaction, the pathogen, P. cryptogea, produces several avirulence factors, known as elicitins. One of the elicitins produced by P. cryptogea is cryptogein, which induces S-nitrosylation of NtCDC48 at Cys526 in Nicotiana cells, compromising its immunity $[99,100]$. An extension of this study suggests the regulation of the ubiquitin-proteasome activity of CDC48 in response to the cryptogein [101]. Table 1 summarizes the association between NO-mediated PTMs and the process of ubiquitylation on target proteins.

Table 1. Ubiquitin-mediated proteasomal degradation of proteins associated with NO-mediated PTMs in plants.

\begin{tabular}{|c|c|c|c|c|c|}
\hline $\begin{array}{c}\text { Targets for } \\
\text { S-Nitrosylation }\end{array}$ & $\begin{array}{l}\text { NO-Mediated } \\
\text { PTMs }\end{array}$ & $\begin{array}{c}\text { Target for } \\
\text { Ubiquitylation }\end{array}$ & $\begin{array}{l}\text { Ubiquitin- } \\
\text { Proteasomal } \\
\text { Machinery }\end{array}$ & Purpose & References \\
\hline ABI5 & $\begin{array}{l}\text { S-nitrosylation } \\
\text { at Cys153 }\end{array}$ & ABI5 & $\begin{array}{l}\text { CULLIN4-based and } \\
\text { KEEP ON GOING } \\
\text { E3 ligases }\end{array}$ & $\begin{array}{l}\text { Germination and early } \\
\text { seed development }\end{array}$ & [78] \\
\hline NPR1 & $\begin{array}{l}\text { S-nitrosylation } \\
\text { at Cys156 }\end{array}$ & NPR1 & $\begin{array}{c}\text { ABA-mediated } \\
\text { degradation through } \\
\text { CULLIN3-RING E3 } \\
\text { ligase and E4 ligase }\end{array}$ & $\begin{array}{l}\text { Protection from } \\
\text { ABA-mediated } \\
\text { proteasomal } \\
\text { degradation. }\end{array}$ & [89] \\
\hline $\begin{array}{c}\text { ABA receptors of } \\
\text { the PYR/PYL/RCAR } \\
\text { family }\end{array}$ & Tyrosine nitration & PYR1 & $\begin{array}{l}\text { Polyubiquitinylation } \\
\text { for degradation. }\end{array}$ & $\begin{array}{c}\text { Reduce the activity of } \\
\text { ABA receptors and } \\
\text { hence limit ABA } \\
\text { response. }\end{array}$ & [86] \\
\hline cAPX1 & $\begin{array}{l}\text { S-nitrosylation } \\
\text { at Cys32 }\end{array}$ & cAPX1 & $\begin{array}{l}\text { Ubiquitylation for } \\
\text { degradation. }\end{array}$ & $\begin{array}{c}\mathrm{H}_{2} \mathrm{O}_{2} \text {-mediated } \\
\text { programed cell death }\end{array}$ & {$[75,76]$} \\
\hline TIR1 & $\begin{array}{l}\text { S-nitrosylation at } \\
\text { Cys140 and Cys480 }\end{array}$ & $\begin{array}{l}\text { Aux/IAA } \\
\text { repressors }\end{array}$ & $\begin{array}{l}\text { E3-ubiquitin ligase } \\
\text { complex, SCF TIR1/AFB }\end{array}$ & $\begin{array}{c}\text { Degradation of } \\
\text { Aux/IAA repressors } \\
\text { to induce } \\
\text { auxin-regulated } \\
\text { responses. }\end{array}$ & [95] \\
\hline CDC48 & $\begin{array}{l}\text { S-nitrosylation } \\
\text { at Cys526 }\end{array}$ & CDC48 & $\begin{array}{c}\text { Itself has } \\
\text { ubiquitin-proteasome } \\
\text { activity }\end{array}$ & $\begin{array}{c}\text { Compromised } \\
\text { immunity against } \\
\text { P. cryptogea }\end{array}$ & {$[99,101]$} \\
\hline
\end{tabular}

\section{Conclusions}

The fundamental role of NO in plant biology has always been fascinating because of its involvement in almost all plant processes, modulating phytohormonal signaling, and environmental acclimation processes. Its involvement in the ubiquitin-mediated proteasomal degradation is yet another interesting discovery that unfolds its regulatory role on other proteins involved in key signaling pathways. The mechanism of NO signal perception and transduction through NO-mediated PTMs has been one of the most-studied signaling mechanisms in plants. In the presence of $\mathrm{NO}$, some regulatory proteins get modified through these NO-mediated PTMs or the N-degron pathway which leads them to degradation via ubiquitylation. NO-mediated PTMs may also target the components of ubiquitylation machinery for inducing the degradation of proteins. Recently, NO sensing through the N-degron pathway has gained much attention due to its direct NO sensing mechanism which directs the target proteins to ubiquitin-mediated proteasomal degradation. Moreover, as in the case of NPR1, NO-mediated PTMs may be involved in the protection of regulatory proteins from degradation due to their key role in plant immune response or other environmental conditions, which further associates NO signaling to the ubiquitylation process. Hence, there seems to be a clear link between NO sensing and the 
ubiquitylation of proteins for maintaining the cellular homeostasis in plants for survival under changing environmental conditions. Further experimental research needs to be done to clearly elucidate the link between NO-mediated PTMs and ubiquitylation.

Author Contributions: Conceptualization, B.-W.Y.; Writing-Original Draft Preparation A.P.; Investigation, W.R.; Resources, G.-M.L.; Writing-Review \& Editing, M.K. and T.N.I.A.A.; Visualization, D.-S.L.; Supervision, A.H.; Project Administration, B.-G.M.; Funding Acquisition, B.-W.Y. All authors have read and agreed to the published version of the manuscript.

Funding: This research was supported by the Basic Science Research Program through the National Research Foundation of Korea (NRF), funded by the Ministry of Education (Grant number 2020R1I1A3073247), Republic of Korea, and the Korea Basic Science Institute (National Research Facilities and Equipment Center) grant funded by the Ministry of Education (2021R1A6C101A416).

Conflicts of Interest: The authors declare no conflict of interest.

\section{References}

1. Delledonne, M.; Xia, Y.; Dixon, R.A.; Lamb, C. Nitric oxide functions as a signal in plant disease resistance. Nature 1998, 394, 585-588. [CrossRef] [PubMed]

2. Durner, J.; Wendehenne, D.; Klessig, D.F. Defense gene induction in tobacco by nitric oxide, cyclic GMP, and cyclic ADP-ribose. Proc. Natl. Acad. Sci. USA 1998, 95, 10328-10333. [CrossRef] [PubMed]

3. Palmer, R.M.; Ferrige, A.; Moncada, S. Nitric oxide release accounts for the biological activity of endothelium-derived relaxing factor. Nature 1987, 327, 524-526. [CrossRef] [PubMed]

4. Beligni, M.V.; Lamattina, L. Nitric oxide stimulates seed germination and de-etiolation, and inhibits hypocotyl elongation, three light-inducible responses in plants. Planta 2000, 210, 215-221. [CrossRef] [PubMed]

5. Pagnussat, G.C.; Simontacchi, M.; Puntarulo, S.; Lamattina, L. Nitric oxide is required for root organogenesis. Plant Physiol. 2002, 129, 954-956. [CrossRef] [PubMed]

6. Corpas, F.J.; Leterrier, M.; Valderrama, R.; Airaki, M.; Chaki, M.; Palma, J.M.; Barroso, J.B. Nitric oxide imbalance provokes a nitrosative response in plants under abiotic stress. Plant Sci. 2011, 181, 604-611. [CrossRef]

7. De Pinto, M.C.; Paradiso, A.; Leonetti, P.; de Gara, L. Hydrogen peroxide, nitric oxide and cytosolic ascorbate peroxidase at the crossroad between defence and cell death. Plant J. 2006, 48, 784-795. [CrossRef]

8. De Michele, R.; Vurro, E.; Rigo, C.; Costa, A.; Elviri, L.; di Valentin, M.; Careri, M.; Zottini, M.; Sanita di Toppi, L.; lo Schiavo, F. Nitric oxide is involved in cadmium-induced programmed cell death in Arabidopsis suspension cultures. Plant Physiol. 2009, 150, 217-228. [CrossRef]

9. Lin, A.; Wang, Y.; Tang, J.; Xue, P.; Li, C.; Liu, L.; Hu, B.; Yang, F.; Loake, G.J.; Chu, C. Nitric oxide and protein S-nitrosylation are integral to hydrogen peroxide-induced leaf cell death in rice. Plant Physiol. 2012, 158, 451-464. [CrossRef]

10. Serrano, I.; Romero-Puertas, M.C.; Rodríguez-Serrano, M.; Sandalio, L.M.; Olmedilla, A. Peroxynitrite mediates programmed cell death both in papillar cells and in self-incompatible pollen in the olive (Olea europaea L.). J. Exp. Bot. 2012, 63, 1479-1493. [CrossRef]

11. Gupta, K.J.; Kolbert, Z.; Durner, J.; Lindermayr, C.; Corpas, F.J.; Brouquisse, R.; Barroso, J.B.; Umbreen, S.; Palma, J.M.; Hancock, J.T. Regulating the regulator: Nitric oxide control of post-translational modifications. New Phytol. 2020, 227, 1319-1325. [CrossRef] [PubMed]

12. Astier, J.; Lindermayr, C. Nitric oxide-dependent posttranslational modification in plants: An update. Int. J. Mol. Sci. 2012, 13, 15193-15208. [CrossRef] [PubMed]

13. Astier, J.; Rasul, S.; Koen, E.; Manzoor, H.; Besson-Bard, A.; Lamotte, O.; Jeandroz, S.; Durner, J.; Lindermayr, C.; Wendehenne, D. S-nitrosylation: An emerging post-translational protein modification in plants. Plant Sci. 2011, 181, 527-533. [CrossRef] [PubMed]

14. Gibbs, D.J.; Bacardit, J.; Bachmair, A.; Holdsworth, M.J. The eukaryotic N-end rule pathway: Conserved mechanisms and diverse functions. Trends Cell Biol. 2014, 24, 603-611. [CrossRef] [PubMed]

15. Gibbs, D.J.; Isa, N.M.; Movahedi, M.; Lozano-Juste, J.; Mendiondo, G.M.; Berckhan, S.; Marín-de la Rosa, N.; Conde, J.V.; Correia, C.S.; Pearce, S.P. Nitric oxide sensing in plants is mediated by proteolytic control of group VII ERF transcription factors. Mol. Cell 2014, 53, 369-379. [CrossRef] [PubMed]

16. Varshavsky, A. N-degron and C-degron pathways of protein degradation. Proc. Natl. Acad. Sci. USA 2019, 116, 358-366. [CrossRef]

17. Moon, J.; Parry, G.; Estelle, M. The ubiquitin-proteasome pathway and plant development. Plant Cell 2004, 16, 3181-3195. [CrossRef]

18. Vierstra, R.D. The ubiquitin-26S proteasome system at the nexus of plant biology. Nat. Rev. Mol. Cell Biol. $2009,10,385-397$. [CrossRef]

19. Doroodian, P.; Hua, Z. The ubiquitin switch in plant stress response. Plants 2021, 10, 246. [CrossRef]

20. Ma, X.; Zhang, C.; Kim, D.Y.; Huang, Y.; Chatt, E.; He, P.; Vierstra, R.D.; Shan, L. Ubiquitylome analysis reveals a central role for the ubiquitin-proteasome system in plant innate immunity. Plant Physiol. 2021, 185, 1943-1965. [CrossRef] 
21. Miricescu, A.; Goslin, K.; Graciet, E. Ubiquitylation in plants: Signaling hub for the integration of environmental signals. J. Exp. Bot. 2018, 69, 4511-4527. [CrossRef] [PubMed]

22. He, D.; Damaris, R.N.; Li, M.; Khan, I.; Yang, P. Advances on Plant Ubiquitylome-From Mechanism to Application. Int. J. Mol. Sci. 2020, 21, 7909. [CrossRef] [PubMed]

23. Su, T.; Yang, M.; Wang, P.; Zhao, Y.; Ma, C. Interplay between the ubiquitin proteasome system and ubiquitin-mediated autophagy in plants. Cells 2020, 9, 2219. [CrossRef] [PubMed]

24. Srivastava, M.; Sadanandom, A. An insight into the factors influencing specificity of the sumo system in plants. Plants 2020, 9, 1788. [CrossRef]

25. Denuc, A.; Marfany, G. SUMO and ubiquitin paths converge. Biochem. Soc. Trans. 2010, 38, 34-39. [CrossRef]

26. Hua, Z.; Yu, P. Diversifying evolution of the ubiquitin-26S proteasome system in Brassicaceae and Poaceae. Int. J. Mol. Sci. 2019, 20, 3226. [CrossRef]

27. Sadhu, A.; Moriyasu, Y.; Acharya, K.; Bandyopadhyay, M. Nitric oxide and ROS mediate autophagy and regulate Alternaria alternata toxin-induced cell death in tobacco BY-2 cells. Sci. Rep. 2019, 9, 1-14. [CrossRef]

28. Dmitrieva, S.; Ponomareva, A.; Gurjanov, O.; Mazina, A.; Andrianov, V.; Iyudin, V.; Minibayeva, F. Spermine induces autophagy in plants: Possible role of no and reactive oxygen species. In Doklady Biochemistry and Biophysics; Pleiades Publishing: New York, NY, USA, 2018; pp. 341-343.

29. Zhan, N.; Wang, C.; Chen, L.; Yang, H.; Feng, J.; Gong, X.; Ren, B.; Wu, R.; Mu, J.; Li, Y. S-nitrosylation targets GSNO reductase for selective autophagy during hypoxia responses in plants. Mol. Cell 2018, 71, 142-154.e146. [CrossRef]

30. Skelly, M.J.; Malik, S.I.; Le Bihan, T.; Bo, Y.; Jiang, J.; Spoel, S.H.; Loake, G.J. A role for S-nitrosylation of the SUMO-conjugating enzyme SCE1 in plant immunity. Proc. Natl. Acad. Sci. USA 2019, 116, 17090-17095. [CrossRef]

31. Park, B.S.; Song, J.T.; Seo, H.S. Arabidopsis nitrate reductase activity is stimulated by the E3 SUMO ligase AtSIZ1. Nat. Commun. 2011, 2, 1-10. [CrossRef]

32. Haas, A.L.; Warms, J.; Hershko, A.; Rose, I.A. Ubiquitin-activating enzyme. Mechanism and role in protein-ubiquitin conjugation. J. Biol. Chem. 1982, 257, 2543-2548. [CrossRef]

33. Hatfield, P.M.; Gosink, M.M.; Carpenter, T.B.; Vierstra, R.D. The ubiquitin-activating enzyme (E1) gene family in Arabidopsis thaliana. Plant J. 1997, 11, 213-226. [CrossRef] [PubMed]

34. Kraft, E.; Stone, S.L.; Ma, L.; Su, N.; Gao, Y.; Lau, O.-S.; Deng, X.-W.; Callis, J. Genome analysis and functional characterization of the E2 and RING-type E3 ligase ubiquitination enzymes of Arabidopsis. Plant Physiol. 2005, 139, 1597-1611. [CrossRef] [PubMed]

35. Lee, J.-H.; Kim, W.T. Regulation of abiotic stress signal transduction by E3 ubiquitin ligases in Arabidopsis. Mol. Cells 2011, 31, 201-208. [CrossRef] [PubMed]

36. Koegl, M.; Hoppe, T.; Schlenker, S.; Ulrich, H.D.; Mayer, T.U.; Jentsch, S. A novel ubiquitination factor, E4, is involved in multiubiquitin chain assembly. Cell 1999, 96, 635-644. [CrossRef]

37. Huang, Y.; Minaker, S.; Roth, C.; Huang, S.; Hieter, P.; Lipka, V.; Wiermer, M.; Li, X. An E4 ligase facilitates polyubiquitination of plant immune receptor resistance proteins in Arabidopsis. Plant Cell 2014, 26, 485-496. [CrossRef]

38. Thrower, J.S.; Hoffman, L.; Rechsteiner, M.; Pickart, C.M. Recognition of the polyubiquitin proteolytic signal. EMBO J. 2000, 19, 94-102. [CrossRef]

39. Reits, E.A.; Benham, A.M.; Plougastel, B.; Neefjes, J.; Trowsdale, J. Dynamics of proteasome distribution in living cells. EMBO J. 1997, 16, 6087-6094. [CrossRef]

40. Enenkel, C.; Lehmann, A.; Kloetzel, P.M. Subcellular distribution of proteasomes implicates a major location of protein degradation in the nuclear envelope-ER network in yeast. EMBO J. 1998, 17, 6144-6154. [CrossRef]

41. Russell, S.J.; Steger, K.A.; Johnston, S.A. Subcellular localization, stoichiometry, and protein levels of $26 \mathrm{~S}$ proteasome subunits in yeast. J. Biol. Chem. 1999, 274, 21943-21952. [CrossRef]

42. Pack, C.-G.; Yukii, H.; Toh-e, A.; Kudo, T.; Tsuchiya, H.; Kaiho, A.; Sakata, E.; Murata, S.; Yokosawa, H.; Sako, Y. Quantitative live-cell imaging reveals spatio-temporal dynamics and cytoplasmic assembly of the $26 \mathrm{~S}$ proteasome. Nat. Commun. 2014, 5, 1-10. [CrossRef] [PubMed]

43. Yang, P.; Fu, H.; Walker, J.; Papa, C.M.; Smalle, J.; Ju, Y.-M.; Vierstra, R.D. Purification of the Arabidopsis 26 S proteasome: Biochemical and molecular analyses revealed the presence of multiple isoforms. J. Biol. Chem. 2004, 279, 6401-6413. [CrossRef] [PubMed]

44. Bedford, L.; Paine, S.; Sheppard, P.W.; Mayer, R.J.; Roelofs, J. Assembly, structure, and function of the 26S proteasome. Trends Cell Biol. 2010, 20, 391-401. [CrossRef] [PubMed]

45. Finley, D.; Prado, M.A. The proteasome and its network: Engineering for adaptability. Cold Spring Harb. Perspect. Biol. 2020, 12, a033985. [CrossRef]

46. Ewan, R.; Pangestuti, R.; Thornber, S.; Craig, A.; Carr, C.; O'Donnell, L.; Zhang, C.; Sadanandom, A. Deubiquitinating enzymes AtUBP12 and AtUBP13 and their tobacco homologue NtUBP12 are negative regulators of plant immunity. New Phytol. 2011, 191, 92-106. [CrossRef] [PubMed]

47. Jeong, J.S.; Jung, C.; Seo, J.S.; Kim, J.-K.; Chua, N.-H. The deubiquitinating enzymes UBP12 and UBP13 positively regulate MYC2 levels in jasmonate responses. Plant Cell 2017, 29, 1406-1424. [CrossRef]

48. Gibbs, D.J.; Lee, S.C.; Isa, N.M.; Gramuglia, S.; Fukao, T.; Bassel, G.W.; Correia, C.S.; Corbineau, F.; Theodoulou, F.L.; Bailey-Serres, J. Homeostatic response to hypoxia is regulated by the N-end rule pathway in plants. Nature 2011, 479, 415-418. [CrossRef] 
49. Gibbs, D.J.; Tedds, H.M.; Labandera, A.-M.; Bailey, M.; White, M.D.; Hartman, S.; Sprigg, C.; Mogg, S.L.; Osborne, R.; Dambire, C. Oxygen-dependent proteolysis regulates the stability of angiosperm polycomb repressive complex 2 subunit VERNALIZATION 2. Nat. Commun. 2018, 9, 1-11. [CrossRef]

50. Weits, D.A.; Kunkowska, A.B.; Kamps, N.C.; Portz, K.M.; Packbier, N.K.; Venza, Z.N.; Gaillochet, C.; Lohmann, J.U.; Pedersen, O.; van Dongen, J.T. An apical hypoxic niche sets the pace of shoot meristem activity. Nature 2019, 569, 714-717. [CrossRef]

51. Holman, T.J.; Jones, P.D.; Russell, L.; Medhurst, A.; Tomás, S.Ú.; Talloji, P.; Marquez, J.; Schmuths, H.; Tung, S.-A.; Taylor, I. The N-end rule pathway promotes seed germination and establishment through removal of ABA sensitivity in Arabidopsis. Proc. Natl. Acad. Sci. USA 2009, 106, 4549-4554. [CrossRef]

52. Graciet, E.; Walter, F.; Maoiléidigh, D.Ó.; Pollmann, S.; Meyerowitz, E.M.; Varshavsky, A.; Wellmer, F. The N-end rule pathway controls multiple functions during Arabidopsis shoot and leaf development. Proc. Natl. Acad. Sci. USA 2009, 106, 13618-13623. [CrossRef] [PubMed]

53. Schuessele, C.; Hoernstein, S.N.; Mueller, S.J.; Rodriguez-Franco, M.; Lorenz, T.; Lang, D.; Igloi, G.L.; Reski, R. Spatio-temporal patterning of arginyl-tRNA protein transferase (ATE) contributes to gametophytic development in a moss. New Phytol. 2016, 209, 1014-1027. [CrossRef] [PubMed]

54. Vicente, J.; Mendiondo, G.M.; Movahedi, M.; Peirats-Llobet, M.; Juan, Y.-T.; Shen, Y.-Y.; Dambire, C.; Smart, K.; Rodriguez, P.L.; Charng, Y.-Y. The Cys-Arg/N-end rule pathway is a general sensor of abiotic stress in flowering plants. Curr. Biol. 2017, 27, 3183-3190.e3184. [CrossRef] [PubMed]

55. Riber, W.; Müller, J.T.; Visser, E.J.; Sasidharan, R.; Voesenek, L.A.; Mustroph, A. The greening after extended darkness1 is an N-end rule pathway mutant with high tolerance to submergence and starvation. Plant Physiol. 2015, 167, 1616-1629. [CrossRef] [PubMed]

56. de Marchi, R.; Sorel, M.; Mooney, B.; Fudal, I.; Goslin, K.; Kwaśniewska, K.; Ryan, P.T.; Pfalz, M.; Kroymann, J.; Pollmann, S. The $\mathrm{N}$-end rule pathway regulates pathogen responses in plants. Sci. Rep. 2016, 6, 1-15. [CrossRef] [PubMed]

57. Dissmeyer, N. Conditional protein function via N-degron pathway-mediated proteostasis in stress physiology. Annu. Rev. Plant Biol. 2019, 70, 83-117. [CrossRef]

58. Nakano, T.; Suzuki, K.; Fujimura, T.; Shinshi, H. Genome-wide analysis of the ERF gene family in Arabidopsis and rice. Plant Physiol. 2006, 140, 411-432. [CrossRef]

59. Foyer, C.H.; Noctor, G. Redox sensing and signalling associated with reactive oxygen in chloroplasts, peroxisomes and mitochondria. Physiol. Plant. 2003, 119, 355-364. [CrossRef]

60. Czarnocka, W.; Karpiński, S. Friend or foe? Reactive oxygen species production, scavenging and signaling in plant response to environmental stresses. Free Radic. Biol. Med. 2018, 122, 4-20. [CrossRef]

61. Hamanaka, R.B.; Chandel, N.S. Mitochondrial reactive oxygen species regulate hypoxic signaling. Curr. Opin. Cell Biol. 2009, 21, 894-899. [CrossRef]

62. Holdsworth, M.J.; Gibbs, D.J. Comparative biology of oxygen sensing in plants and animals. Curr. Biol. 2020, 30, R362-R369. [CrossRef] [PubMed]

63. Bates, P.W.; Vierstra, R.D. UPL1 and 2, two 405 kDa ubiquitin-protein ligases from Arabidopsis thaliana related to the HECTdomain protein family. Plant J. 1999, 20, 183-195. [CrossRef] [PubMed]

64. Iglesias, M.J.; Casalongué, C.A.; Terrile, M.C. Ubiquitin-proteasome system as part of nitric oxide sensing in plants. In Nitric Oxide in Plant Biology; Elsevier: Amsterdam, The Netherlands, 2022; pp. 653-687.

65. Van, V.; Smith, A.T. ATE1-mediated post-translational arginylation is an essential regulator of eukaryotic cellular homeostasis. ACS Chem. Biol. 2020, 15, 3073-3085. [CrossRef] [PubMed]

66. Labandera, A.M.; Tedds, H.M.; Bailey, M.; Sprigg, C.; Etherington, R.D.; Akintewe, O.; Kalleechurn, G.; Holdsworth, M.J.; Gibbs, D.J. The PRT6 N-degron pathway restricts VERNALIZATION 2 to endogenous hypoxic niches to modulate plant development. New Phytol. 2021, 229, 126-139. [CrossRef] [PubMed]

67. Wang, Y.; Yun, B.-W.; Kwon, E.; Hong, J.K.; Yoon, J.; Loake, G.J. S-nitrosylation: An emerging redox-based post-translational modification in plants. J. Exp. Bot. 2006, 57, 1777-1784. [CrossRef]

68. Lubega, J.; Umbreen, S.; Loake, G.J. Recent advances in the regulation of plant immunity by S-nitrosylation. J. Exp. Bot. 2021, 72, 864-872. [CrossRef]

69. Lindermayr, C.; Saalbach, G.; Durner, J.r. Proteomic identification of S-nitrosylated proteins in Arabidopsis. Plant Physiol. 2005, 137, 921-930. [CrossRef]

70. Yun, B.W.; Skelly, M.J.; Yin, M.; Yu, M.; Mun, B.G.; Lee, S.U.; Hussain, A.; Spoel, S.H.; Loake, G.J. Nitric oxide and Snitrosoglutathione function additively during plant immunity. New Phytol. 2016, 211, 516-526. [CrossRef]

71. Yun, B.-W.; Feechan, A.; Yin, M.; Saidi, N.B.; Le Bihan, T.; Yu, M.; Moore, J.W.; Kang, J.-G.; Kwon, E.; Spoel, S.H. S-nitrosylation of NADPH oxidase regulates cell death in plant immunity. Nature 2011, 478, 264-268. [CrossRef]

72. Wang, Y.-Q.; Feechan, A.; Yun, B.-W.; Shafiei, R.; Hofmann, A.; Taylor, P.; Xue, P.; Yang, F.-Q.; Xie, Z.-S.; Pallas, J.A. S-nitrosylation of AtSABP3 antagonizes the expression of plant immunity. J. Biol. Chem. 2009, 284, 2131-2137. [CrossRef]

73. Spoel, S.H.; Loake, G.J. Redox-based protein modifications: The missing link in plant immune signalling. Curr. Opin. Plant Biol. 2011, 14, 358-364. [CrossRef]

74. Lindermayr, C.; Sell, S.; Müller, B.; Leister, D.; Durner, J. Redox regulation of the NPR1-TGA1 system of Arabidopsis thaliana by nitric oxide. Plant Cell 2010, 22, 2894-2907. [CrossRef] [PubMed] 
75. Yang, H.; Mu, J.; Chen, L.; Feng, J.; Hu, J.; Li, L.; Zhou, J.-M.; Zuo, J. S-nitrosylation positively regulates ascorbate peroxidase activity during plant stress responses. Plant Physiol. 2015, 167, 1604-1615. [CrossRef] [PubMed]

76. De Pinto, M.C.; Locato, V.; Sgobba, A.; Romero-Puertas, M.d.C.; Gadaleta, C.; Delledonne, M.; de Gara, L. S-nitrosylation of ascorbate peroxidase is part of programmed cell death signaling in tobacco Bright Yellow-2 cells. Plant Physiol. 2013, 163, 1766-1775. [CrossRef] [PubMed]

77. Ding, Y.; Dommel, M.; Mou, Z. Abscisic acid promotes proteasome-mediated degradation of the transcription coactivator NPR 1 in Arabidopsis thaliana. Plant J. 2016, 86, 20-34. [CrossRef]

78. Albertos, P.; Romero-Puertas, M.C.; Tatematsu, K.; Mateos, I.; Sánchez-Vicente, I.; Nambara, E.; Lorenzo, O. S-nitrosylation triggers ABI5 degradation to promote seed germination and seedling growth. Nat. Commun. 2015, 6, 1-10. [CrossRef]

79. Davletova, S.; Rizhsky, L.; Liang, H.; Shengqiang, Z.; Oliver, D.J.; Coutu, J.; Shulaev, V.; Schlauch, K.; Mittler, R. Cytosolic ascorbate peroxidase 1 is a central component of the reactive oxygen gene network of Arabidopsis. Plant Cell 2005, 17, 268-281. [CrossRef]

80. Foyer, C.H.; Noctor, G. Ascorbate and glutathione: The heart of the redox hub. Plant Physiol. 2011, 155, 2-18. [CrossRef]

81. Correa-Aragunde, N.; Cejudo, F.J.; Lamattina, L. Nitric oxide is required for the auxin-induced activation of NADPH-dependent thioredoxin reductase and protein denitrosylation during root growth responses in arabidopsis. Ann. Bot. 2015, 116, 695-702. [CrossRef]

82. Rizza, S.; Montagna, C.; Di Giacomo, G.; Cirotti, C.; Filomeni, G. S-nitrosation and ubiquitin-proteasome system interplay in neuromuscular disorders. Int. J. Cell Biol. 2014, 2014. [CrossRef]

83. Melcher, K.; Ng, L.-M.; Zhou, X.E.; Soon, F.-F.; Xu, Y.; Suino-Powell, K.M.; Park, S.-Y.; Weiner, J.J.; Fujii, H.; Chinnusamy, V. A gate-latch-lock mechanism for hormone signalling by abscisic acid receptors. Nature 2009, 462, 602-608. [CrossRef]

84. Santiago, J.; Rodrigues, A.; Saez, A.; Rubio, S.; Antoni, R.; Dupeux, F.; Park, S.Y.; Márquez, J.A.; Cutler, S.R.; Rodriguez, P.L. Modulation of drought resistance by the abscisic acid receptor PYL5 through inhibition of clade A PP2Cs. Plant J. 2009, 60, 575-588. [CrossRef] [PubMed]

85. Lozano-Juste, J.; Leoün, J. Enhanced abscisic acid-mediated responses in nia1nia2noa1-2 triple mutant impaired in NIA/NR-and AtNOA1-dependent nitric oxide biosynthesis in Arabidopsis. Plant Physiol. 2010, 152, 891-903. [CrossRef] [PubMed]

86. Castillo, M.-C.; Lozano-Juste, J.; González-Guzmán, M.; Rodriguez, L.; Rodriguez, P.L.; León, J. Inactivation of PYR/PYL/RCAR ABA receptors by tyrosine nitration may enable rapid inhibition of ABA signaling by nitric oxide in plants. Sci. Signal. 2015, 8, ra89. [CrossRef] [PubMed]

87. Pieterse, C.M.; Van Wees, S.C.; Van Pelt, J.A.; Knoester, M.; Laan, R.; Gerrits, H.; Weisbeek, P.J.; Van Loon, L.C. A novel signaling pathway controlling induced systemic resistance in Arabidopsis. Plant Cell 1998, 10, 1571-1580. [CrossRef]

88. Backer, R.; Naidoo, S.; van den Berg, N. The NONEXPRESSOR OF PATHOGENESIS-RELATED GENES 1 (NPR1) and related family: Mechanistic insights in plant disease resistance. Front. Plant Sci. 2019, 10, 102. [CrossRef]

89. Tada, Y.; Spoel, S.H.; Pajerowska-Mukhtar, K.; Mou, Z.; Song, J.; Wang, C.; Zuo, J.; Dong, X. Plant immunity requires conformational charges of NPR1 via S-nitrosylation and thioredoxins. Science 2008, 321, 952-956. [CrossRef]

90. Spoel, S.H.; Mou, Z.; Tada, Y.; Spivey, N.W.; Genschik, P.; Dong, X. Proteasome-mediated turnover of the transcription coactivator NPR1 plays dual roles in regulating plant immunity. Cell 2009, 137, 860-872. [CrossRef]

91. Chung, K.K.; Thomas, B.; Li, X.; Pletnikova, O.; Troncoso, J.C.; Marsh, L.; Dawson, V.L.; Dawson, T.M. S-nitrosylation of parkin regulates ubiquitination and compromises parkin's protective function. Science 2004, 304, 1328-1331. [CrossRef]

92. Nakamura, T.; Wang, L.; Wong, C.C.; Scott, F.L.; Eckelman, B.P.; Han, X.; Tzitzilonis, C.; Meng, F.; Gu, Z.; Holland, E.A Transnitrosylation of XIAP regulates caspase-dependent neuronal cell death. Mol. Cell 2010, 39, 184-195. [CrossRef]

93. Kapadia, M.R.; Eng, J.W.; Jiang, Q.; Stoyanovsky, D.A.; Kibbe, M.R. Nitric oxide regulates the 26S proteasome in vascular smooth muscle cells. Nitric Oxide 2009, 20, 279-288. [CrossRef]

94. Hu, J.; Huang, X.; Chen, L.; Sun, X.; Lu, C.; Zhang, L.; Wang, Y.; Zuo, J. Site-specific nitrosoproteomic identification of endogenously S-nitrosylated proteins in Arabidopsis. Plant Physiol. 2015, 167, 1731-1746. [CrossRef] [PubMed]

95. Terrile, M.C.; París, R.; Calderón-Villalobos, L.I.; Iglesias, M.J.; Lamattina, L.; Estelle, M.; Casalongué, C.A. Nitric oxide influences auxin signaling through S-nitrosylation of the Arabidopsis TRANSPORT INHIBITOR RESPONSE 1 auxin receptor. Plant J. 2012, 70, 492-500. [CrossRef] [PubMed]

96. Baek, G.H.; Cheng, H.; Choe, V.; Bao, X.; Shao, J.; Luo, S.; Rao, H. Cdc48: A swiss army knife of cell biology. J. Amino Acids 2013, 2013. [CrossRef] [PubMed]

97. Hirsch, C.; Gauss, R.; Horn, S.C.; Neuber, O.; Sommer, T. The ubiquitylation machinery of the endoplasmic reticulum. Nature 2009, 458, 453-460. [CrossRef] [PubMed]

98. Noguchi, M.; Takata, T.; Kimura, Y.; Manno, A.; Murakami, K.; Koike, M.; Ohizumi, H.; Hori, S.; Kakizuka, A. ATPase activity of p97/valosin-containing protein is regulated by oxidative modification of the evolutionally conserved cysteine 522 residue in Walker A motif. J. Biol. Chem. 2005, 280, 41332-41341. [CrossRef] [PubMed]

99. Astier, J.; Besson-Bard, A.; Lamotte, O.; Bertoldo, J.; Bourque, S.; Terenzi, H.; Wendehenne, D. Nitric oxide inhibits the ATPase activity of the chaperone-like AAA+ ATPase CDC48, a target for S-nitrosylation in cryptogein signalling in tobacco cells. Biochem. J. 2012, 447, 249-260. [CrossRef] [PubMed] 
100. Rosnoblet, C.; Bègue, H.; Blanchard, C.; Pichereaux, C.; Besson-Bard, A.; Aimé, S.; Wendehenne, D. Functional characterization of the chaperon-like protein Cdc48 in cryptogein-induced immune response in tobacco. Plant Cell Environ. 2017, 40, 491-508. [CrossRef]

101. Rosnoblet, C.; Chatelain, P.; Klinguer, A.; Bègue, H.; Winckler, P.; Pichereaux, C.; Wendehenne, D. The chaperone-like protein Cdc48 regulates ubiquitin-proteasome system in plants. Plant Cell Environ. 2021. [CrossRef] 